\title{
Evaluation of Glucosamine and Snail Mucin on the Progression of Experimental Knee Osteoarthritis in Dogs
}

\author{
Evaluación de la Glucosamina y Mucina de Caracol en la Progresión \\ de la Osteoartritis Experimental de Rodilla en Perros
}

Adetola R. Ajadi*; Oladele, S. Gazal ${ }^{* *}$; Ebenezer, B. Otesile* \& Olajide, B. Kasali***

\begin{abstract}
AJADI, A. R.; GAZAL, O. S.; OTESILE, E. B. \& KASALI, O. B. Evaluation of glucosamine and snail mucin on the progression of experimental knee osteoarthritis in dogs. Int. J. Morphol., 31(1):280-286, 2013.

SUMMARY: This study evaluated the effect of oral glucosamine and intramuscular injection (IM) of snail mucin on the progression of experimental osteoarthritis (OA) in dogs. Twenty adult mongrels with mean body weight $(12.4 \pm 1.8 \mathrm{~kg})$ were used. Experimental OA was induced surgically using the groove model. The dogs were randomly divided into three groups following radiographic evidence of OA. Group one (control) comprised of ten dogs treated with normal saline twice weekly for four weeks following OA. Group two comprised of five dogs treated with $10 \mathrm{mg} / \mathrm{kg}$ of oral glucosamine daily for four weeks. Group three comprised of five dogs treated with $5 \mathrm{mg} / \mathrm{kg}$ intramuscular injection of $5 \%$ solution of snail mucin twice weekly for four weeks. Blood was obtained from the cephalic vein before surgical arthrotomy, after surgical arthrotomy, immediately after radiographic confirmation of OA (Week 0) and at two weeks interval up to 4 weeks of treatment. Efficacy of the drugs was assessed by changes in plasma IL-6 and MMP-3, while safety was determined using the changes in packed cell volume (PCV), total white blood cell counts (WBC) and observable adverse reactions associated with the administration of the drugs. In this study, the PCV and WBC did not differ significantly (P>0.05) from the control group. Plasma IL-6 and MMP-3 were significantly $(\mathrm{P}<0.05)$ lower both in glucosamine-treated and snail mucin-treated dogs up to week 4 of treatment when compared with the control group. However, there were no significant $(\mathrm{P}>0.05)$ differences in IL-6 and MMP-3 between the two treatment groups. In addition, painful swelling at the site of injection was observed in dogs treated with snail mucin, while no adverse reaction was observed in dogs treated with oral glucosamine. It was therefore concluded that both oral glucosamine and IM injection of snail mucin comparably modified the progression of OA. However, owing to the adverse reaction noted with IM injection of snail mucin, further study is required to determine the most appropriate route of administration.
\end{abstract}

KEY WORDS: Osteoarthritis; Snail mucin; Glucosamine; Interleukin; Matrix metalloproteinase; Dogs.

\section{INTRODUCTION}

Osteoarthritis (OA) is a degenerative joint disease characterized by damage to the articular cartilage and changes in the subchondral bone, and frequently accompanied by secondary synovitis (Lepine \& Hayek, 2001). The disease is insidious and develops over many years. It is a major cause of impaired mobility particularly among women. Osteoarthritis has been estimated to be the 8th leading non-fatal burden of disease in the world and accounted for 3 percent of global years of living with disability (Symmon et al., 2003). The estimated prevalence of symptomatic OA in populations above the age of 65 is 30 percent (Slemenda et al., 1998). Osteoarthritis is more frequent in dogs than in cats. In dogs, the onset of primary
OA depends on breed. The onset mean age is 3.5 years in Rottweilers and 9.5 years in Poodles (Patronek et al., 1997. The incidence of canine OA is increased by trauma as well as obesity, ageing and genetic abnormalities.

Osteoarthritis (OA) is a complex disease that encompasses all the tissues within a joint. OA was historically regarded as a non-inflammatory arthritis, but recent evidence has shown there is an inflammatory component to OA (Kuroki et al., 2005; Scanzello et al., 2008). While progressive destruction of articular cartilage with subsequent narrowing of the joint space is often considered a hallmark of OA, other intra-articular tissues

\footnotetext{
* Department of Veterinary Medicine \& Surgery, Federal University of Agriculture, Abeokuta, Nigeria.

** Department of Biological Sciences, St. Cloud State University, St. Cloud, Minnesota, USA.

**** Department of Veterinary Pathology, Federal University of Agriculture, Abeokuta, Nigeria.
} 
are not spared. Synovitis, meniscal tears, osteophyte formation and joint swelling can all occur, and each affected tissue sends signals in the form of pro-inflammatory cytokines to the others. These signals augment destruction, thus promoting the harmful cycle. No single cytokine is the sole mediator of joint damage, and the adverse effects are likely the result of a complex interaction of cytokines (Fernandes et al., 2002; Hegemann et al., 2005; Hulejová et al., 2007), proteolytic enzymes (Borzi et al., 2000), leukocytes (Sandell et al., 2008), synoviocytes (Villiger et al., 1992) and chondrocytes (Kuroki et al.).

Oral glucosamine is widely used in an attempt to palliate the pain and disability of OA, and is a component of a large number of dietary supplements (Block et al., 2009). It is also of great interest in the fitness and athletics communities because of claims that it has cartilage building and lubricant properties for the joints (Gorsline \& Kaedine, 2005). Its popularity has grown despite ongoing controversy regarding its effectiveness (versus placebo), safety, and possible mechanisms of action (Hochberg, 2006; Vlad et al., 2007). In vitro studies have shown that glucosamine inhibits interleukin-1- induced nitric oxide production and has a modest anti-inflammatory effect in the rat (Gorsline \& Kaedine).

The land snail has been used in medicine since antiquity. The mucus from snail has been reported to slow down the inflammation of the lungs (Bonnemain, 2005). Also the lecithin from the land snail has been used as a prognostic indicator for some cancers such as those of the breast, stomach and colon (Dwek et al., 2001). Recently acharan sulphate, a mucin from Achatina fulica has been demonstrated to act as an angiogenesis inhibitor and as an antitumor agent through the inhibition of matrix metalloproteinase activity (Lee et al., 2003). Mucin from jelly fish has been described to have potential diseasemodifying effects on osteoarthritis on rabbit cartilage (Ohta et al., 2009). This action was believed to be due to the ability of the mucin to improve the viscosity and friction properties of the synovial fluid and enhance self- assembly capacity of the cartilage. With the promise that the mucin from snail can be a potential disease modifying osteoarthritis agent (DMOA), we compared the potential osteoarthritic effect of snail mucin to that of glucosamine in an experimental model of knee OA in dogs.

\section{MATERIAL AND METHOD}

Animals. Twenty adult mongrel dogs with mean weight of $12.4 \pm 1.8 \mathrm{~kg}$, and age ranging between $1-3$ years (mean age $=$
$2.1 \pm 0.3$ years) were used. They were adjudged to be free of any musculoskeletal disease based on the visual assessment of gait, palpation and radiographic evaluation of the joints. In addition, they were adjudged to be clinically healthy based on results of faecal examination, complete blood counts and physical examinations. The dogs were housed individually in concrete -floored kennels and allowed moderate exercise daily. They were fed once daily on cooked rice supplemented with sufficient amount of proteins and palm oil, while water was provided ad libitum. Ethical approval for this study was obtained from the Research Ethics Committee, College of Veterinary Medicine, Federal University of Agriculture, Abeokuta.

Preparation of snail mucin. Snail mucin was extracted according to the methods described by Nnamani \& Adikwu (2006). Matured land snails (Archatina marginata) were washed in distilled water, knocked open at the apex and a spirally coiled rod inserted to remove the fleshy body from the excretory parts. The fleshy part were then placed in about $250 \mathrm{~mL}$ of distilled water and washed severally until the mucin was completely washed off. Washings from several snails were then pooled together in a plastic bucket and precipitated using chilled acetone and then freeze dried. The lyophilized flakes of mucin were then pulverized into fine powder and stored in an air-tight container until needed.

\section{Experimental groove model of canine osteoarthritis. The} procedure for experimental OA was done according to the method described by Frost- Christensen et al. (2008). The dogs were premedicated with intramuscular injections of atropine sulphate (Atocan ${ }^{\circledR}$, Sishui Xierkang Pharma, China) at $0.03 \mathrm{mg} / \mathrm{kg}$ and xylazine hydrochloride (XYL-M2®, $\mathrm{VMD}$, Belgium) at $1.0 \mathrm{mg} / \mathrm{kg}$. Following premedication, size 21 gauge scalp- vein needle was inserted into the cephalic vein to secure the venous access and the cardiovascular system maintained with lactated Ringers solution at the rate of $0.2 \mathrm{ml} / \mathrm{kg} / \mathrm{h}$. Thereafter, anaesthesia was induced and maintained with a combination of diazepam (Calmpose ${ }$, Ranbaxy, Dewas, India) at the rate of $0.3 \mathrm{mg} / \mathrm{kg}$ and ketamine hydrochloride (Rotexmedica ${ }^{\circledR}$, Trittau, Germany) at the rate of $10 \mathrm{mg} / \mathrm{kg}$. The right knee was then prepared aseptically. Thereafter, about $5 \mathrm{~cm}$ para-patellar incision was made. Bleeding was controlled and soft tissue damage was kept to the minimum. The joint capsule was incised with a scalpel and then lengthened with scissors. Thereafter, femoral condyle was then exposed by flexing the joint maximally. Cartilage of the lateral and medial femoral condyles were then grooved $(0.5 \mathrm{~mm}$ depths $)$ in utmost flexion. Longitudinal and diagonal grooves were made on the weight bearing parts of the femoral condyles without damaging the subchondral bone. The joint capsule, subcutis and the skin were then closed separately. The dogs were allowed to 
recuperate for two weeks before the commencement of the study. During this period, the dogs were treated with penicillin/ streptomycin injection (Strepcillin $®$, MobedcoVet, Jordan) for five days and pain was controlled using tramadol injection (Amadol®, Union Korea Pharma, Korea) at $3 \mathrm{mg} / \mathrm{kg}$. In addition, the joint was loaded for 30 $\mathrm{min} / \mathrm{d}$ by fixing the contralateral leg to the trunk.

Design. This study was a controlled, randomized, blinded design involving three groups. Group one (control) comprised of ten dogs treated with normal saline twice weekly for four weeks following experimentally- induced OA. Group two comprised of five dogs treated with 10mg/ $\mathrm{kg}$ of oral glucosamine (Glycoflex ${ }^{\circledR}$, Vetri- Science Laboratories, USA) daily for four weeks following OA. Group three comprised of five dogs treated with $5 \mathrm{mg} / \mathrm{kg}$ intramuscular injection of $5 \%$ solution of snail mucin twice weekly for four weeks following OA.

Experimental Procedure. Following surgical arthrotomy of the right knee, the dogs were allowed to recover for two weeks. During this period, the operated leg was moderately loaded by attaching the contralateral leg to the trunk. The leg was loaded for thirty minutes daily and repeated thrice weekly. In addition, $3 \mathrm{mg} / \mathrm{kg}$ of Tramadol injection was administered to relieve pain. Thereafter, they were assessed fortnightly by radiographical examination until radiographic evidence of OA was confirmed on the operated knee. Following radiographical evidence of osteoarthritis on the operated knee, the dogs were then randomly assigned to any of the groups. Treatment was done for four weeks after which the treatment was discontinued and experiment terminated. During treatment, adverse effects associated with the drugs such as pain or swelling at the site of the injection, vomition, diarrhoea and behavioural changes were noted as at when they occurred.

Measurements. About $5 \mathrm{ml}$ of blood was obtained from the cephalic vein of the dogs before arthrotomy (BA), 24 hours after arthrotomy (AA), after radiographic confirmation of osteoarthritis (Week 0) and thereafter, fortnightly until the end of the treatment for the determination of packed cell volume (PCV), total white blood cell counts (WBC), plasma concentration of Interleukin- 6, and canine matrix metalloproteinase 3 (MMP-3).

Blood analysis. The PCV and WBC were determined with automated blood analyzer. The plasma levels of interleukin6 (IL-6) was assayed using quantitative sandwich enzyme immunoassay technique (Quantikine ${ }^{\circledR}, \mathrm{R} \& \mathrm{D}$ Systems, McKinley Place, Minneapolis, USA). Plasma level of Canine Matrix Metalloproteinase 3 (MMP-3) was assayed using quantitative sandwich enzyme immunoassay technique (Cusabio Biotech Co., LTD., Wuhan University Science Park, Wuhan, China). The optical densities of the wells were determined within 30 minutes, using a microplate reader set at $450 \mathrm{~nm}$ and $540 \mathrm{~nm}$. A standard curve was created with either IL- 6 or MMP-3 on the y-axis and the absorbance on the $\mathrm{x}$-axis. Intra-assay precision (CV \%) was less than $8 \%$, while inter-assay precision (CV \%) was less than $10 \%$.

Statistical Analysis. Data were presented as mean \pm standard deviation (SD). Changes in PCV, WBC, IL-6 and MMP-3 were compared between the different groups using analysis of variance (ANOVA) for repeated measures. All statistical analysis was performed using SPSS 17.0 software (SPSS Inc., Chicago, IL, USA). Differences were considered significant when $\mathrm{P}$ value was less or equal to 0.05 .

\section{RESULTS}

There were no observable adverse reactions following oral administration of glucosamine in the dogs. However, dogs treated with intramuscular injection of snail mucin developed painful swelling at the site of injection by the end of the second week of treatment necessitating the treatment to be discontinued. The swelling however,

Table I. Packed Cell Volume (\%) of dogs treated with either glucosamine or snail mucin following experimental knee osteoarthritis.

\begin{tabular}{lccc}
\hline Period of Assessment & Control & Glucosamine (GLU) & Snail Mucin (MUC) \\
\hline Before Arthrotomy (BA) & $33.9 \pm 4.2 \mathrm{a}$ & $34.3 \pm 5.9 \mathrm{a}$ & $34.2 \pm 4.0 \mathrm{a}$ \\
1Week after Arthrotomy & $33.4 \pm 3.6 \mathrm{a}$ & $34.0 \pm 6.1 \mathrm{a}$ & $33.7 \pm 3.0 \mathrm{a}$ \\
Week 0 of treatment & $37.3 \pm 4.3 \mathrm{a}$ & $35.5 \pm 6.1 \mathrm{a}$ & $36.2 \pm 3.1 \mathrm{a}$ \\
Week 2 of treatment & $39.3 \pm 5.3 \mathrm{a}$ & $37.8 \pm 5.7 \mathrm{a}$ & $38.6 \pm 4.2 \mathrm{a}$ \\
Week 4 of treatment & $39.5 \pm 6.8 \mathrm{a}$ & $41.0 \pm 3.3 \mathrm{a}$ & $40.2 \pm 3.1 \mathrm{a}$ \\
\hline
\end{tabular}


AJADI, A. R.; GAZAL, O. S.; OTESILE, E. B. \& KASALI, O. B. Evaluation of glucosamine and snail mucin on the progression of experimental knee osteoarthritis in dogs. Int. J. Morphol., 31(1):280-286, 2013.

Table II. White blood cell counts (x106/L) of dogs treated with either glucosamine or snail mucin following experimental knee osteoarthritis.

\begin{tabular}{lccc}
\hline Period of Assessment & Control & Glucosamine (GLU) & Snail Mucin (MUC) \\
\hline Before arthrotomy (BA) & $9.8 \pm 3.8^{\mathrm{a}}$ & $12.2 \pm 6.2 \mathrm{a}$ & $7.3 \pm 1.7^{\mathrm{a}}$ \\
1 Week after arthrotomy & $21.3 \pm 4.5^{\mathrm{b}}$ & $17.8 \pm 7.7 \mathrm{~b}$ & $20.9 \pm 3.4^{\mathrm{b}}$ \\
Week 0 of treatment & $20.8+5.6 \mathrm{~b}$ & $19.5 \pm 5.0 \mathrm{~b}$ & $18.4 \pm 4.1^{\mathrm{b}}$ \\
Week 2 of treatment & $19.5 \pm 7.6 \mathrm{~b}$ & $16.7 \pm 4.3 \mathrm{~b}$ & $25.4 \pm 7.8^{\mathrm{c}}$ \\
Week 4 of treatment & $20.6 \pm 5.4 \mathrm{~b}$ & $7.3 \pm 1.1 \mathrm{a}$ & $8.0 \pm 2.3^{\mathrm{a}}$ \\
\hline
\end{tabular}

$\mathrm{P} \leq 0.05$; a,b values with different superscripts are statistically significant.

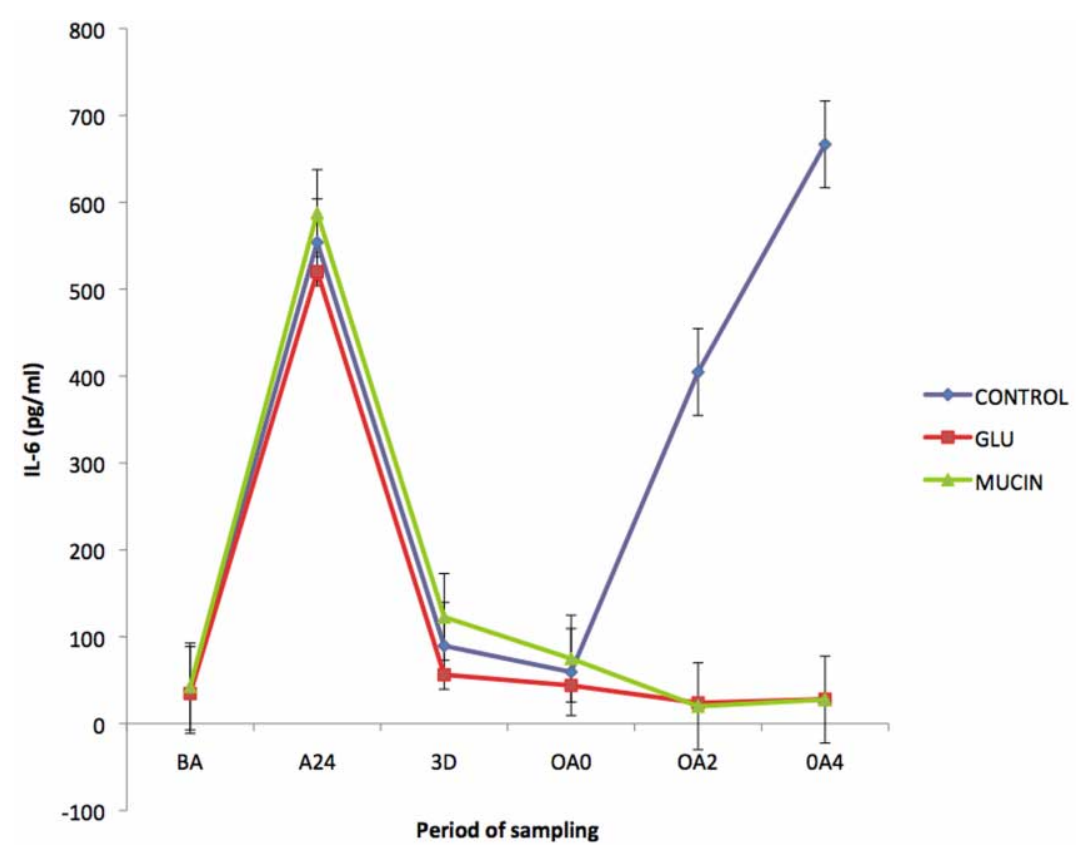

Fig. 1. Changes in plasma IL-6 in dogs treated with either oral glucosamine or intramuscular injection of snail mucin following experimental osteoarthritis.

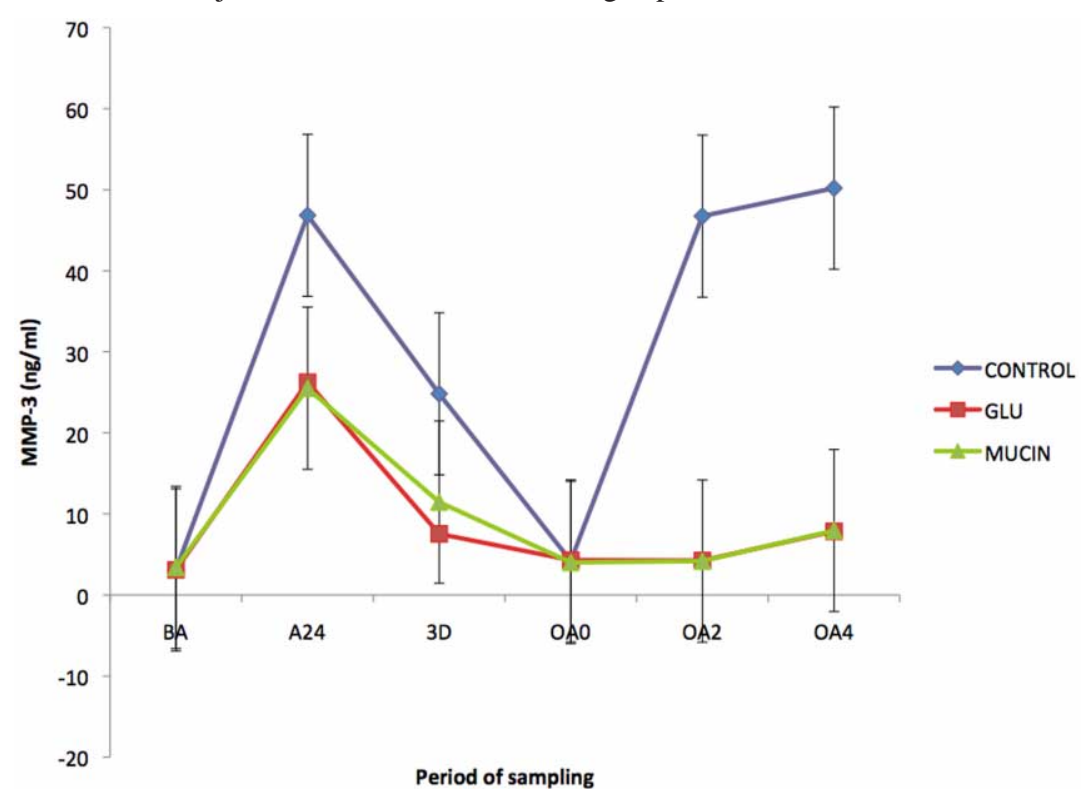

Fig. 2. Changes in plasma MMP-3 in dogs treated with either oral glucosamine or intramuscular injection of snail mucin following experimental osteoarthritis. disappeared about one week later without any treatment.

There were no significant differences in the packed cell volume (PCV) between the treated dogs and the control dogs. Similarly, there were no significant differences in the PCV between glucosamine- treated dogs and the snail mucin-treated dogs (Table I). However, the total white cell counts (WBC) increased significantly $(\mathrm{P}<0.05)$ from the baseline up to week $\mathrm{O}$ of treatment in both the control and the treated dogs. Also, the WBC was significantly $(\mathrm{P}<0.05)$ higher by week 2 of treatment in the snail mucin- treated dogs than the glucosamine-treated dogs. However, there was no significant difference in the WBC by week 4 of OA between the two treatment groups (Table II).

Following experimental OA, plasma IL-6 and MMP-3 was significantly $(\mathrm{P}<0.05)$ higher in control dogs than dogs treated with either oral glucosamine or intramuscular injection of snail mucin. However, there was no significant difference in plasma IL-6 and MMP-3 between dogs treated with oral glucosamine and dogs treated with intramuscular injection of snail mucin (Fig. 1). Similarly, plasma MMP-3 did not differ significantly between glucosamine treated and mucin treated dogs, however, the MMP-3 values in the treated dogs was significantly higher than in the control dogs (Fig. 2). 


\section{DISCUSSION}

The results of this study showed that both glucosamine and snail mucin inhibited the progression of experimentallyinduced osteoarthritis in dogs as indicated by the lowered values of IL-6 and MMP-3. There were no differences in plasma concentration of IL- 6 and MMP-3 following administration of glucosamine or snail mucin. None of the agents adversely affected the packed cell volume and the total white cell count. However, intramuscular injection of snail mucin elicited painful swelling at the site of injection.

IL-6 is the most important acute-phase protein inducer. In humans, IL-6 strongly stimulates hepatocytes to produce C-reactive protein (CRP), fibrinogen, haptoglobin and antichymotrypsin (Weinhold \& Ruther, 1997). IL-6 also acts synergistically with other cytokines, enhancing the proliferation of multipotentials hematopoietic progenitors and promote the maturation of human megakaryocytes (Fonseca et al., 2009). In this study, plasma IL-6 was elevated 24 hours after arthrotomy and then decreased progressively up to 24 day of OA. Thereafter, the plasma level of IL-6 increased significantly up to week 4 of OA. This finding further confirmed the pro-inflammatory role of IL-6 in the pathogenesis of OA. IL-6 probably stimulates the production of both acute phase response proteins as well as joint proteinases to drive forward the process of osteoarthritis.

Progressive degradation of the extracellular matrix (ECM) of joint tissues, including articular cartilage, bone, intra-articular ligaments and tendons, is a major feature of the arthritic diseases (Murphy et al., 2002). This event leads to permanent loss of function. Although proteinases of all mechanistic classes play a role in the degradation of connective tissue macromolecules, it has long been known that the major activities involved in this process belong to the family of MMPs (Sandya et al., 2009). These enzymes are secreted by both the resident cells of joint tissues as well as by invading cells. These proteinases are active around neutral values of $\mathrm{pH}$, and they have the combined ability to degrade all the components of the ECM. MMPs play significant roles in both developmental and repair processes, and it appears that aberrant regulation, which can occur at many levels leads to their hyperactivity in diseases such as rheumatoid arthritis (RA) and OA.

MMP-3 is one of the members of the matrix metalloproteinase. It has affinity for collagen type-IX. The plasma levels of MMP-3 have been reported to be correlated with radiographic progression of OA in humans (Takahashi et al., 2004). In this study, plasma MMP-3 increased with the duration of OA in the dogs. It is also note-worthy that there is correlation between the pattern of changes in IL-6 and MMP-3, thus suggesting that IL-6 initiates the release of MMP-3 which in-turn is responsible for cartilage degradation during OA. Thus, drugs that can inhibit the release of either IL-6 or MMP-3 may significantly modify the progression of $\mathrm{OA}$.

Glucosamine is an amino sugar that acts as a precursor in the biosynthesis of GAGs and proteoglycan aggregates (de los Reyes et al., 2000). The biologic mechanisms underlying the apparent benefits of glucosamine remain obscure. One of the possible physiologic roles of exogenous glucosamine is to function as an additional source of hexosamine and sulfate precursors for GAG synthesis (de los Reyes et al.). Oral glucosamine hydrochloride prevents the loss of GAG in joint cartilage damaged by intra-articular injection of chymopapain (Oegema et al., 2002). In addition to their constitutive roles in the joint, glucosamine also possess anti-inflammatory properties. In vitro studies have shown that glucosamine inhibits cartilage catabolic responses and prevents IL-1b-induced increases in nitric oxide synthesis (Häuselmann, 2001; Fenton et al., 2002). Studies in vitro suggest that combined glucosamine and chondroitin sulfate may decrease the gelatinolytic activity of MMP-9 (Orth et al., 2002). In this study, oral glucosamine administered daily for four weeks inhibited the elevation of both plasma IL-6 and MMP-3 suggesting that glucosamine might act by regulating the release of both IL- 6 and MMP-3. It is logical to conclude that since MMP-3 and IL-6 are involved the catabolic processes that cumulate in the degradation of joint cartilage; glucosamine does modify the progression of OA.

The result of this study showed that the osteoarthritic effect of snail mucin is comparable with that of glucosamine. This is so because there was no significant difference in the plasma concentration of both IL-6 and MMP-3 after 4 weeks of administration of both agents to dogs with experimental OA. It is noteworthy to say that the dosage of snail mucin administered in this study is based on our previous study in dogs (Ajadi \& Martins, 2011). We cannot tell whether this dosage is equipotent to the dose of glucosamine administered in this study or not. Thus, further work is required to determine the appropriate dosage of snail mucin injection for treatment of OA in dogs.

Finally, caution should be exercised while interpreting the outcome of this study. First, the model of osteoarthritis used does not represent the natural OA in humans and dogs and thus the biological changes noted 
may not be completely the same for natural OA. The model used in this study will represent events that followed posttraumatic OA. It may be that the anti-osteoarthritic effect of both glucosamine and snail mucin reported here are actually due to their anti-inflammatory effect on the regulation of the activity of IL-6 and MMP-3. The short duration of this study also, might not have allowed for sufficient time for complete process of OA to develop. In humans and dogs, natural OA might take over two years to develop and can progress over lifetime. This is one of the limitations of using animal models for studying pattern of OA in humans. However, the result of this study is encouraging and further supports the previous evidences on the putative role of glucosamine on the progression of OA. It also provides evidences on the usefulness of snail mucin in the treatment of OA.

AJADI, A. R.; GAZAL, O. S.; OTESILE, E. B. \& KASALI, O. B. Evaluación de la glucosamina y mucina de caracol en la progresión de la osteoartritis experimental de rodilla en perros. Int. J. Morphol., 31(1):280-286, 2013.

RESUMEN: Se evaluaron los efectos de la glucosamina oral y la inyección intramuscular (IM) de mucina de caracol en la progresión de la osteoartritis (OA) experimental en perros. Fueron utilizados 20 perros mestizos adultos con un peso medio de 12,4 $\pm 1,8 \mathrm{~kg}$. La OA experimental se indujo quirúrgicamente mediante el modelo de ranura. Los animales se dividieron aleatoriamente en tres grupos después de la evidencia radiográfica de OA. El grupo 1 (control, 10 perros) fue tratado con una solución salina normal dos veces por semana durante cuatro semanas. El grupo 2 (5 perros) fue tratado con $10 \mathrm{mg} / \mathrm{kg}$ de glucosamina oral al día por cuatro semanas, y el grupo 3 (5 perros) fue tratado con $5 \mathrm{mg} / \mathrm{kg}$ IM de una solución de mucina de caracol al $5 \%$ dos veces por semana durante cuatro semanas. Se obtuvieron muestras de sangre desde la vena cefálica previo a la artrotomía quirúrgica, después de la artrotomía e inmediatamente después de la confirmación radiográfica de $\mathrm{OA}$ (semana 0), y en el intervalo de dos semanas hasta cuatro semanas de tratamiento. La eficacia de los fármacos se evaluó por los cambios plasmáticos de IL-6 y MMP-3, mientras que la seguridad, se determinó por los cambios en el volumen del hematocrito $(\mathrm{VH})$, el recuento total de glóbulos blancos (RGB), y la observación de reacciones adversas asociadas a la administración de fármacos. El VH y RGB no difirieron significativamente $(\mathrm{P}>0,05)$ en el grupo control. Los niveles de IL-6 y MMP-3 plasmática fueron significativamente más bajas $(\mathrm{P}<0,05)$ en los perros tratados con glucosamina y mucina de caracol hasta 4 semanas, en comparación con el grupo control. Sin embargo, no hubo diferencias significativas $(\mathrm{P}>0,05)$ en la IL-6 y MMP-3 entre los dos grupos de tratamiento. Además, se observó un edema doloroso en el sitio de inyección de los perros tratados con mucina de caracol. En los perros tratados con glucosamina oral no se observó reacción adversa. Se concluye que tanto la glucosamina oral y la inyección IM de mucina de caracol modifican comparablemente la progresión de OA. Sin embargo, debido a la reacción adversa observada con la inyección IM de mucina caracol, se necesitan estudios adicionales para determinar la vía de administración más adecuada.

PALABRAS CLAVE: Osteoartritis; Mucina de caracol; Glucosamina; Interleuquina; Metaloproteinasas de la matriz; Perros.

\section{REFERENCES}

Ajadi, R. A. \& Martins, M. M. Preliminary Evaluation of the efficacy and safety of snail mucin on experimental osteoarthritis in dogs. Bio-Research, 9(2):15-23, 2011.

Borzí, R. M.; Mazzetti, I.; Cattini, L.; Uguccioni, M.; Baggiolini, M. \& Facchini, A. Human chondrocytes express functional chemokine receptors and release matrix-degrading enzymes in response to C-X-C and C-C chemokines. Arthritis Rheum., 43(8):1734-41, 2000.

Block, J. A.; Oegema, T. R.; Sandy, J. D. \& Plaas, A. The effect of oral glucosamine on joint health: is a change in research approach needed? Osteoarthritis Cartilage, 18(1):5-11, 2010.

Bonnemain, B. Helix and Drugs: Snails for Western Health Care From Antiquity to the Present. Evid. Based Complement. Alternat. Med., 2(1):25-28, 2005.

de los Reyes, G. C.; Koda, R. T. \& Lien, E. J. Glucosamine and chondroitin sulfates in the treatment of osteoarthritis. Prog. Drug. Res., 55:81-103, 2000.
Dwek, M. V.; Ross, H. A.; Streets, A. J.; Brooks, S. A.; Adam, E.; Titcomb, A.; et al. Helix pomatia agglutinin lectin-binding oligosaccharides of aggressive breast cancer. Int. J. Cancer, 95(2):79-85, 2001.

Fenton, J. I.; Chlebek-Brown, K. A.; Caron, J. P. \& Orth, M. W. Effect of glucosamine on interleukin-1-conditioned articular cartilage. Equine Vet. J. Suppl., (34):219-23, 2002.

Fernandes, J. C.; Martel-Pelletier, J. \& Pelletier, J. P. The role of cytokines in osteoarthritis pathophysiology. Biorheology, 39(1-2):237-46, 2002.

Fonseca, J. E.; Santos, M. J.; Canhão, H. \& Choy, E. Interleukin-6 as a key player in systemic inflammation and joint destruction. Autoimmun. Rev., 8(7):538-42, 2009

Frost-Christensen, L. N.; Mastbergen, S. C.; Vianen, M. E.; Hartog, A.; DeGroot, J.; Voorhout, G.; et al. Degeneration, inflammation, regeneration, and pain/disability in dogs following destabilization or articular cartilage grooving of the stifle joint. Osteoarthritis Cartilage, 16(11):1327-35, 2008. 
Gorsline, R. T. \& Kaeding, C. C. The use of NSAIDs and nutritional supplements in athletes with osteoarthritis: prevalence, benefits, and consequences. Clin. Sports Med., 24(1):71-82, 2005.

Häuselmann, H. J. Nutripharmaceuticals for osteoarthritis. Best. Pract. Res. Clin. Rheumatol., 15(4):595-607, 2001.

Hegemann, N.; Wondimu, A.; Kohn, B.; Brunnberg, L. \& Schmidt, M. F. Cytokine profile in canine immune-mediated polyarthritis and osteoarthritis. Vet. Comp. Orthop. Traumatol., 18(2):6772,2005 .

Hochberg, M. C. Nutritional supplements for knee osteoarthritis-still no resolution. N. Engl. J. Med., 354(8):858-60, 2006.

Hulejová, H.; Baresová, V.; Klézl, Z.; Polanská, M.; Adam, M. \& Senolt, L. Increased level of cytokines and matrix metalloproteinases in osteoarthritic subchondral bone. Cytokine, 38(3):151-6, 2007.

Kuroki, K.; Stoker, A. M. \& Cook, J. L. Effects of proinflammatory cytokines on canine articular chondrocytes in a three-dimensional culture. Am. J. Vet. Res., 66(7):1187-96, 2005.

Lee, W. M. Drug-induced hepatotoxicity. N. Engl. J. Med., 349(5):474-85, 2003.

Lepine, A. J. \& Hayek, M. G. Articular cartilage in health and disease. In: Clinical Perspectives on Canine Joint Disease. Orlando, Florida, Presented at The North American Veterinary Conference, 2001. pp.8-17.

Murphy, G.; Knauper, V.; Atkinson, S.; Butler, G.; English, W.; Hutton, M.; et al. Matrix metalloproteinases in arthritic diseases. Arthritis Res., 4(Suppl. 3):S39-49, 2002.

Nnamani, P. O. \& Adikwu, M. U. Some physiological and toxicological properties of snail mucin extracted from Archachatina marginata. Bio-Research, 3(2):1-6, 2006.

Oegema, T. R. Jr.; Deloria, L. B.; Sandy, J. D. \& Hart, D. A. Effect of oral glucosamine on cartilage and meniscus in normal and chymopapain-injected knees of young rabbits. Arthritis Rheum., 46(9):2495-503, 2002.

Ohta, N.; Sato, M.; Ushida, K.; Kokubo, M.; Baba, T.; Taniguchi, $\mathrm{K}$; et al. Jellyfish mucin may have potential disease modifying effects on osteoarthritis. BMC Biotechnol., 9:98, 2009.

Orth, M. W.; Peters, T. L. \& Hawkins, J. N. Inhibition of articular cartilage degradation by glucosamine- $\mathrm{HCl}$ and chondroitin sulphate. Equine Vet. J., (34):224-9, 2002.

Patronek, G. J.; Waters, D. J. \& Glickman, L. T. Comparative longevity of pet dogs and humans, Implications for gerontology research. J. Gerontal. A Biol. Sci. Med. Sci., 52(3):B171-8, 1997.
Sandell, L. J.; Xing, X.; Franz, C.; Davies, S.; Chang, L. W. \& Patra, D. Exuberant expression of chemokine genes by adult human articular chondrocytes in response to IL-1beta. Osteoarthritis Cartilage, 16(12):1560-71, 2008.

Sandya, S.; Achan, M. A. \& Sudhakaran, P. R. Multiple matrix metalloproteinases in type II collagen-induced arthritis. India J. Clin. Biochem., 24(1):42-8, 2009.

Scanzello, C. R.; Plaas, A. \& Crow, M. K. Innate immune system activation in osteoarthritis: is osteoarthritis a chronic wound? Curr. Opin. Rheumatol., 20(5):565-72, 2008.

Slemenda, C.; Heilman, D. K.; Brandt, K. D.; Katz, B. P.; Mazzuca, S. A.; Braunstein, E. M.; et al. Reduced quadriceps strength relative to body weight: a risk factor for knee osteoarthritis in women? Arthritis Rheum., 41(11):1951-9, 1998.

Symmons, D.; Mathers, C. \& Pfleger, B. The global burden of arthritis in the year 2000. Geneva, World Health Organization, 2003.

Takahashi, M.; Naito, K.; Abe, M.; Sawada, T. \& Nagado, A. Relationship between radiographic grading of osteoarthritis and the biochemical markers for arthritis in knee osteoarthritis. Arthritis Res. Ther., 6(3):R208-12, 2004.

Villiger, P. M.; Terkeltaub, R. \& Lotz, M. Production of monocyte chemoattractant protein-1 by inflamed synovial tissue and cultured synoviocytes. J. Immunol., 149(2):722-7, 1992.

Vlad, S. C.; LaValley, M. P.; McAlindon, T. E. \& Felson, D. T. Glucosamine for pain in osteoarthritis: why do trial results differ? Arthritis Rheum., 56(7):2267-77, 2007.

Weinhold, B. \& Rüther, U. Interleukin-6-dependent and independent regulation of the human $\mathrm{C}$-reactive protein gene. Biochem. J., 327 (Pt 2):425-9, 1997.

Correspondence to:

Adetola R. Ajadi

Department of Veterinary Medicine \& Surgery

Federal University of Agriculture, PMB 2240

Alabata Road

Abeokuta

Ogun State

NIGERIA

Tel: 234-703-380-0326

Email: ade_vsr@hotmail.com

Received: 01-08-2012

Accepted: 22-10-2012 